\title{
Natryskiwanie łukowe powłok Fe-Al
}

\author{
Arc spraying of Fe-Al coatings
}

\section{Streszczenie}

W artykule przedstawiono wstępne wyniki badań wytwarzania kompozytowych powłok z układu Fe-Al z udziałem faz międzymetalicznych in-situ za pomocą natryskiwania łukowego. Proces natryskiwania prowadzono poprzez jednoczesne topienie dwóch różnych drutów elektrodowych, aluminiowego i stalowego. Celem prowadzonych badań jest wytworzenie powłok ochronnych o kompozytowej strukturze ze znaczącym udziałem faz międzymetalicznych $\mathrm{Fe}_{x} \mathrm{Al}_{y}$, których synteza zachodzi podczas procesu natryskiwania (in-situ). Otrzymane wyniki wykazały lokalne występowanie faz międzymetalicznych z układu Fe-Al, a dominujące składniki struktury to roztwory aluminium w żelazie i żelaza w aluminium. Udział faz międzymetalicznych w powłoce jest stosunkowo niski, lecz jego wpływ na właściwości materiału powłoki jest istotny.

Słowa kluczowe: fazy międzymetaliczne; natryskiwanie łukowe; powłoki; Fe-Al

\begin{abstract}
The paper presents preliminary results of research on the production of composite coatings from the Fe-Al system with participation of intermetallic phases in-situ using arc spraying. The spraying process was carried out by simultaneously melting two different electrode wires, aluminium and steel. The aim of the research is to create protective coatings with a composite structure with a significant participation of $\mathrm{Fe}_{\mathrm{x}} \mathrm{Al}_{\mathrm{y}}$ as a intermetallic phases reinforcement. The synthesis of intermetallic takes place during the (in-situ) spraying process. Currently most of coatings involving intermetallic phases are being manufactured by different thermal spraying methods using coating materials in form of prefabricated powders containing intermetallic phases. The obtained results showed that the local occurrence of intermetallic phases from the Fe-Al system, and the dominant components of the structure are two phases, aluminium solid solutions in iron and iron in aluminium. The participation of intermetallic phases in the coating is relatively low, but it's effect on the properties of the coating material is significant.
\end{abstract}

Keywords: intermetallic phases; arc spraying; coatings; Fe-Al

\section{Wstęp}

Fazy międzymetaliczne z układu Fe-Al oraz Ni-Al są atrakcyjnymi materiałami powłokowymi, które charakteryzują się specyficznymi właściwościami zwłaszcza w porównaniu z konwencjonalnymi metalowymi materiałami powłokowymi. Obecnie, najczęściej powłoki z udziałem faz międzymetalicznych wykonywane są poprzez natryskiwanie cieplne różnymi metodami z prefabrykowanych proszków faz międzymetalicznych. Znane są również z doniesień literaturowych procesy wytwarzania faz międzymetalicznych in-situ na modyfikowanej powierzchni poprzez stopowanie składników [1,2]. Realizując plan badań założono, że podczas natryskiwania łukowego topiąc niezależnie dwa druty stalowy i aluminiowy, wytworzone zostaną termodynamiczne warunki sprzyjające syntezie $w$ trakcie procesu faz międzymetalicznych z układu Fe-Al. Fazy międzymetaliczne z układu Fe-Al dzięki bardzo wysokiej odporności na utlenianie w wysokiej temperaturze (dochodzącej do $900{ }^{\circ} \mathrm{C}$ ), dużej odporności na ścieranie i relatywnie niskiej gęstości, wykorzystywane

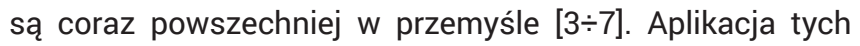
nowoczesnych materiałów w przemyśle energetycznym, wydobywczym i samochodowym została opisana w literaturze $[8,9,11]$. Problem utrudniający stosowanie powłok Fe-Al wynika z ich kruchości w temperaturze otoczenia oraz trudności z kształtowaniem metodami obróbki mechanicznej gotowych elementów na żądany wymiar $[7,8,10]$. Zaproponowana w pracy metoda wytwarzania faz międzymetalicznych może stanowić alternatywę dla obecnie stosowanych, znacznie droższych, rozwiązań opartych głównie na proszkach intermetalicznych nanoszonych metodą HVOF i APS [12].

\section{Natryskiwanie łukowe}

Metalizacja natryskowa, której jedną z odmian jest natryskiwanie łukowe, zaliczana jest do grupy cieplno-mechanicznych metod wytwarzania powłok. Materiał powlekający podawany jest w postaci dwóch jednakowych drutów.

Mgr inż. Piotr Siwek; dr hab. inż. Tomasz Chmielewski, prof. PW - Politechnika Warszawska, dr inż. Marcin Chmielewski - Instytut Technologii Materiałów Elektronicznych.

Autor korespondencyjny/Corresponding author. t.chmielewski@wip.pw.edu.pl 
Łuk elektryczny jarzący się między tymi drutami powoduje ich topienie, sprężone powietrze atomizuje cząstki, przyspieszając je do prędkości dochodzącej do $150 \mathrm{~m} / \mathrm{s}$ i natryskuje je na wcześniej przygotowane podłoże. Jest to proces relatywnie niskoenergetyczny, którego zaletą jest blisko dwukrotnie większa prędkość topienia materiału dodatkowego, niż przy natryskiwaniu płomieniowym. Wydajność natryskiwania łukowego zależy od natryskiwanego materiału i mocy źródła. Proces prowadzony jest zazwyczaj ręcznie lub półautomatycznie, pistolet utrzymywany jest $\mathrm{w}$ odległości $50 \div 200 \mathrm{~mm}$ od pokrywanego przedmiotu. W jednym przejściu uzyskuje się powłokę o grubości od 120 do $250 \mu \mathrm{m}$. Łuk między przewodzącymi prąd drutami powinien się jarzyć w osi dyszy doprowadzającej sprężone powietrze, tak aby sprężone powietrze nadało cząstkom odpowiednio wysoką energię kinetyczną. Schemat procesu przedstawiono na rysunku 1 .

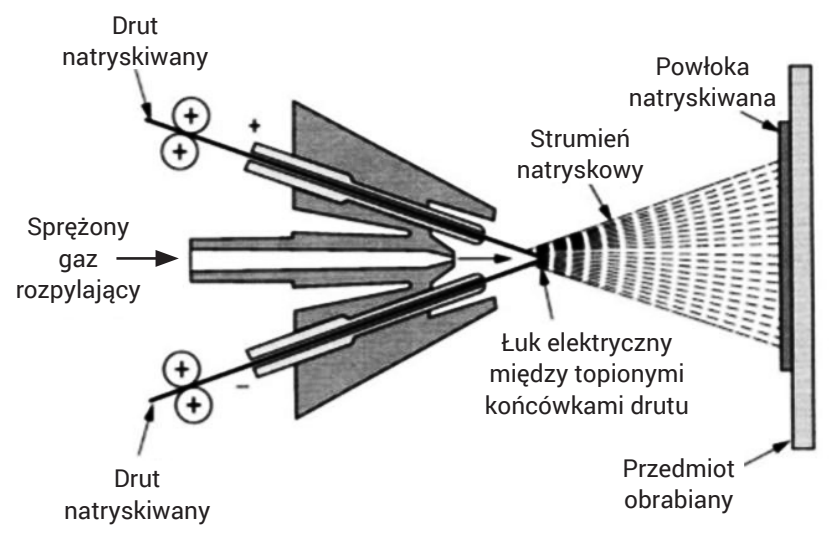

Rys. 1. Schemat natryskiwania łukowego

Fig. 1. Arc spraying scheme

Podstawowymi parametrami natryskiwania łukowego są: napięcie łuku i natężenie prądu, posuw drutów, ciśnienie i przepływ gazu rozpylającego, rodzaj i średnica drutu oraz odległości dyszy od podłoża. Podczas natryskiwania może wystąpić zjawisko indukowania naprężenia wewnątrz powłoki podczas jej stygnięcia, spowodowane jest to uderzaniem nagrzanych cząstek materiału natryskiwanego w podłoże o znacznie niższej temperaturze. Aby tego uniknąć, celowe jest zastosowanie dodatkowego palnika służącego do nagrzewania podłoża, co może stanowić utrudnienie technologiczne. Ograniczeniem metody w stosunku do innych proszkowych metod natryskowych jest utrudnienie nanoszenia warstw z materiałów ceramicznych (nie przewodzą prądu) oraz trudności z produkcją materiałów cermetalowych w postaci drutów rdzeniowych. Do natryskiwania łukowego najczęściej wykorzystuje się: aluminium, cynk, molibden oraz stopy: mosiądz, monel, brąz, stale Cr-Ni oraz ferrytyczno chromowe. Metoda ta wykorzystywana jest powszechnie w przemyśle stoczniowym do pokrywaniu kadłubów statków, w budownictwie lądowym do zabezpieczania elementów mostów oraz do regeneracji części maszyn.

\section{Warunki procesu natryskiwania}

Do wykonania powłoki zastosowano agregat natryskowy firmy Metallisation udostępniony przez firmę SciTeeX sp. z o.o. W procesie natryskiwania wykorzystano dwa różne druty elektrodowe topione jednocześnie, aluminiowy i stalowy (SG2) o średnicy 1,6 mm. Powłokę natryskiwano na płyty ze stali niestopowej S235JR o wymiarach $60 \times 60 \times 5 \mathrm{~mm}$. Przed naniesieniem powłoki próbki zostały poddane obróbce
Tablica I. Parametry natryskiwania łukowego Table I. Parameters of arc spraying

\begin{tabular}{|c|c|}
\hline Parametr & Wartość, jednostka \\
\hline Napięcie łuku & $34 \mathrm{~V}$ \\
\hline Natężenia prądu & $250 \mathrm{~A}$ \\
\hline Średnica drutów elektrodowych & $1,6 \mathrm{~mm}$ \\
\hline Posuw drutów & $2,6 \mathrm{~m} / \mathrm{s}$ \\
\hline Ciśnienie powietrza rozpylającego & $0,3 \mathrm{MPa}$ \\
\hline
\end{tabular}

śrutowaniem ostrokrawędziowym śrutem stalowym w celu oczyszczenia i rozwinięcia powierzchni. Parametry procesu natryskiwania przedstawiono $\mathrm{w}$ tablicy I.

\section{Badania metalograficzne}

Wytworzona powłoka została poddana badaniom metalograficznym w celu scharakteryzowania mikrostruktury oraz analizy fazowej w kierunku potwierdzenia syntezy faz międzymetalicznych. Obserwowano właściwości połączenia podłoża z powłoką. Podczas natryskiwania łukowego połączenie między powłoką a materiałem rodzimym ma charakter adhezyjno-mechaniczny, rozpędzone krople/cząstki uderzając w powierzchnię metalu, odkształcają się plastycznie, przyjmując kształt zależny od struktury streometrycznej podłoża. Powstałe połączenie o charakterze kształtowym/ mechanicznym wnosi do przyczepności powłoki. Uzyskaniu wysokiej przyczepności sprzyja również oczyszczenie powierzchni podłoża, podnosząc w ten sposób wartość energii swobodnej powierzchni. W pierwszej fazie, badania prowadzono na mikroskopie optycznym firmy Olympus wyposażonym w aparat fotograficzny do cyfrowej rejestracji obrazu. Przeprowadzono obserwację zgładów metalograficznych powłoki Fe-Al pod powiększeniem x100 i x200. Przedstawiona na rysunku 2 powłoka charakteryzuje się wielofazową strukturą z mocno odkształconymi płaskimi ziarnami o zmiennej grubości. Podczas badań na mikroskopie optycznym obserwowano trzy różne fazy z ciemnymi obszarami wtrąceń i zanieczyszczeń. Połączenie powłoki z podłożem jest ciągłe bez wyraźnych niedoskonałości. Powłoka jest stosunkowo gęsto upakowana z nielicznymi pustkami i nieciągłościami. Warstwa wierzchnia powłoki posiada stosunkowo wysoką chropowatość i jest falista. Połączenie powłoki z podłożem ma charakter "adhezyjno-mechaniczny" bez widocznej strefy przejściowej.

Powłokę kompozytową, wielofazową Fe-Al naniesioną łukowo na podłoże stalowe poddano badaniu na scaningowym mikroskopie elektronowym. Przedstawiona na rysunku 3 powłoka jest niejednorodna fazowo. Widoczna jest pasmowa struktura z nielicznymi cząstkami o sferycznym kształcie. W powłoce występują obszary o różnym stopniu zaciemnienia w skali szarości. Faza, której odpowiada najciemniejszy kolor ma osnowę Al, faza najjaśniejsza ma osnowę Fe. Występuję również w nieznacznym udziale objętościowym faza o pośrednim stopniu zaciemnienia, którą mogą stanowić intermetaliki z układ Fe-Al o różnej steriometrii. Powłoka nie jest jednorodna na całej grubości.

Pomiary mikrotwardości przeprowadzono na zgładzie w przekroju poprzecznym układu powłoka-podłoże. Zastosowano metodę Vickersa z obciążeniem wgłębnika masą $100 \mathrm{~g}$. W celu określenia niepewności pomiaru przeprowadzono rozkład t-studenta z przyjętym poziomem ufności $95 \%$. Z otrzymanych wyników sporządzono wykres przedstawiający rozkład mikrotwardości. 

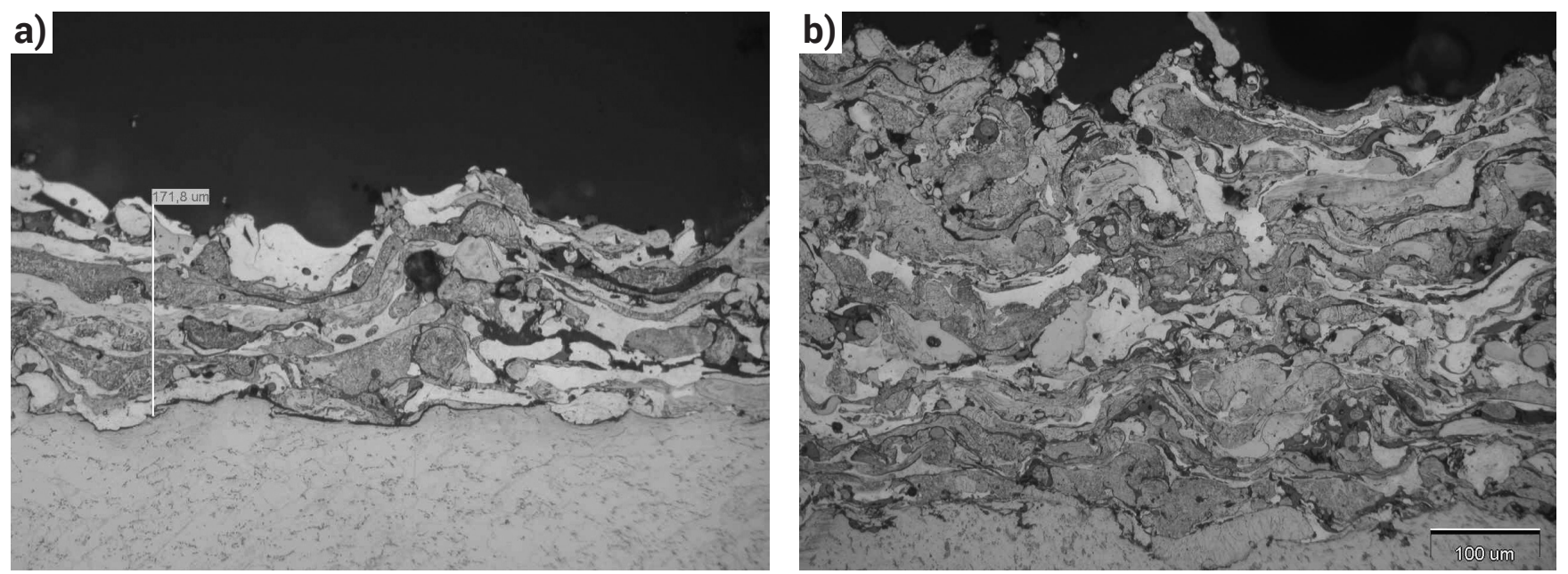

Rys. 2. Mikrostruktura powłoki natryskanej łukowo Fe-Al na podłoże stalowe z pomiarem grubości, a) x100, b) x200

Fig. 2. The microstructure of the Fe-Al sprayed coating on a steel substrate with a thickness measurement, a) x100, b) $\times 200$
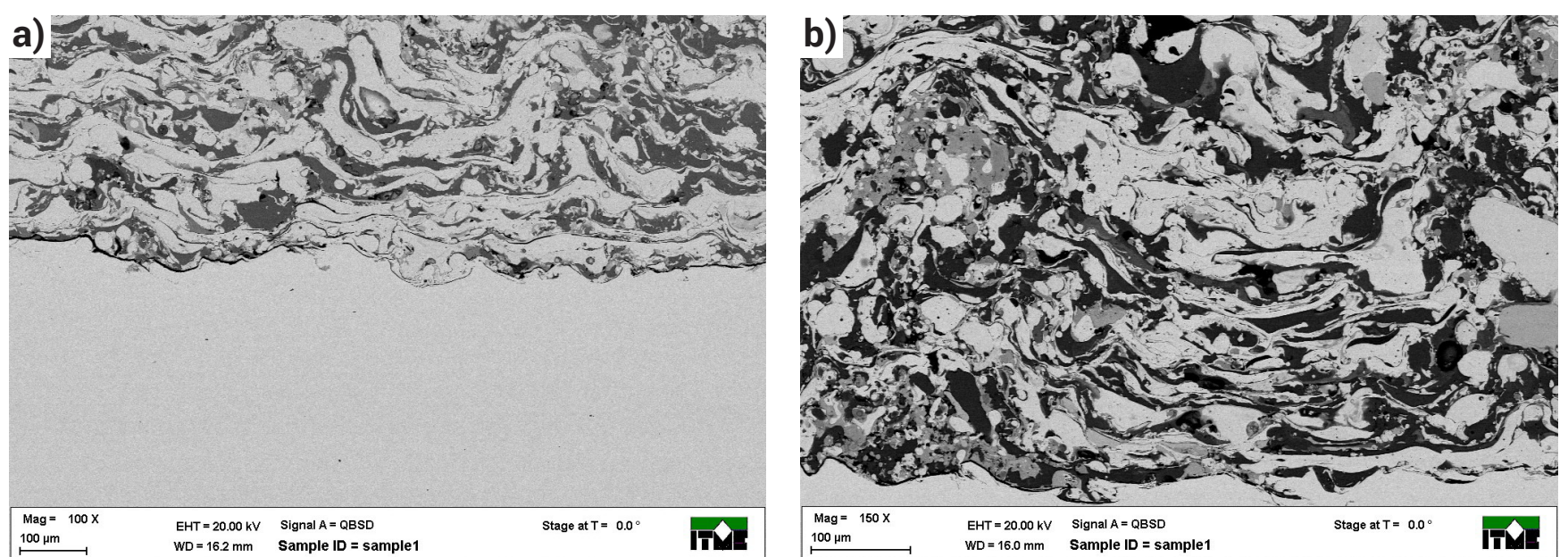

Rys. 3. Obraz SEM mikrostruktury powłoki natryskanej łukowo Fe-Al na podłoże stalowe, a) x100, b) x150

Fig. 3. SEM image of the microstructure of the Fe-Al coating deposited on a steel substrate, a) $\times 100, b) \times 150$

Przedstawiony rozkład mikrotwardości na rysunku 4 wykazuje znaczne różnice $w$ twardości materiału podłoża i powłoki. W pobliżu granicy powłoki i materiału podłoża twardość osiąga najwyższą średnią wartość na poziomie $265 \mu \mathrm{HV} 0,1$ w połowie grubości powłoki twardość jest niższa, na poziomie $230 \mu \mathrm{HV} 0,1$ przy powierzchni twardość wzrasta do $258 \mu \mathrm{HV} 0,1$. Różnice w twardości są spowodowane najprawdopodobniej niejednorodnością w strukturze powłoki oraz różnymi warunkami odprowadzania ciepła w trakcie narastania powłoki. Podczas pomiarów nie odnotowano wartości charakterystycznych dla występowania fazy międzymetalicznej,

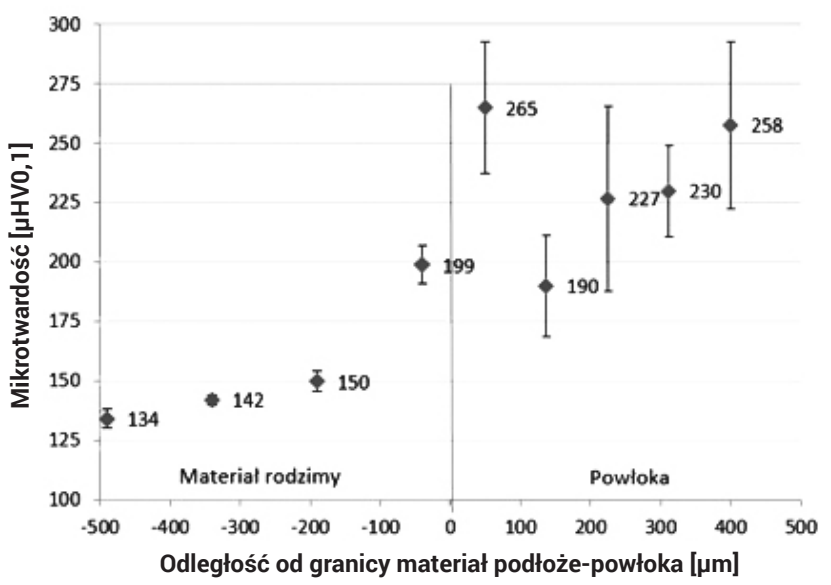

Rys. 4. Rozkład mikrotwardości w materiale rodzimym i powłoce natryskiwanej łukowo Fe-Al

Fig. 4. Distribution of microhardness in the substrate material and Fe-Al arc-sprayed coating której twardość jest znacznie wyższa od otrzymanych wyników, co pozwala zakładać, że synteza faz międzymetalicznych Fe-Al, jeśli zaszła, to tylko lokalnie na granicy międzyfazowej ziaren na osnowie Al i Fe.

\section{Budowa fazowa powłok}

W celu przeanalizowania budowy fazowej powłok w pierwszym etapie wykonano badania XRD. Na rysunku 5 przedstawiono dyfraktogram z którego wynika, że struktura fazowa badanej powłoki zawiera dwie główne fazy o charakterze metalicznym - oparte na strukturze Fe (bcc) i Al (fcc). $W$ rzeczywistości są to roztwory $\mathrm{Fe}(\mathrm{Al})$ i $\mathrm{Al}(\mathrm{Fe})$ z dominującym udziałem rozpuszczalników, przy czym roztwór stały $\mathrm{Fe}(\mathrm{Al})$ ma znacznie większą różnicę stałej sieciowej w stosunku do czystego Fe - sugeruje to większy udział Al w tej fazie. Widoczne są też krystaliczne fazy tlenkowe - oparte na strukturach wustytu (FeO) i magnetytu $\left(\mathrm{Fe}_{3} \mathrm{O}_{4}\right)$. Analiza XRD nie potwierdza istotnego udziału (powyżej czułości metody) w strukturze powłoki faz międzymetalicznych z układu Fe-Al. Przybliżony minimalny udział objętościowy fazy krystalicznej w strukturze identyfikowalny metodą XRD wynosi ok. $5 \%$.

Na rysunku 6 przedstawiono obrazy SEM wydzieleń krystalicznych na granicy międzyfazowej ziaren na osnowie Fe i ziaren na osnowie Al, które występują w całej objętości badanych powłok, lecz z różną intensywnością.

W pierwszym etapie analizy struktury fazowej wydzieleń krystalizacyjnych pokazanych na rysunku 6 przeprowadzono badanie EDS w celu określenia rozkładu liniowego 


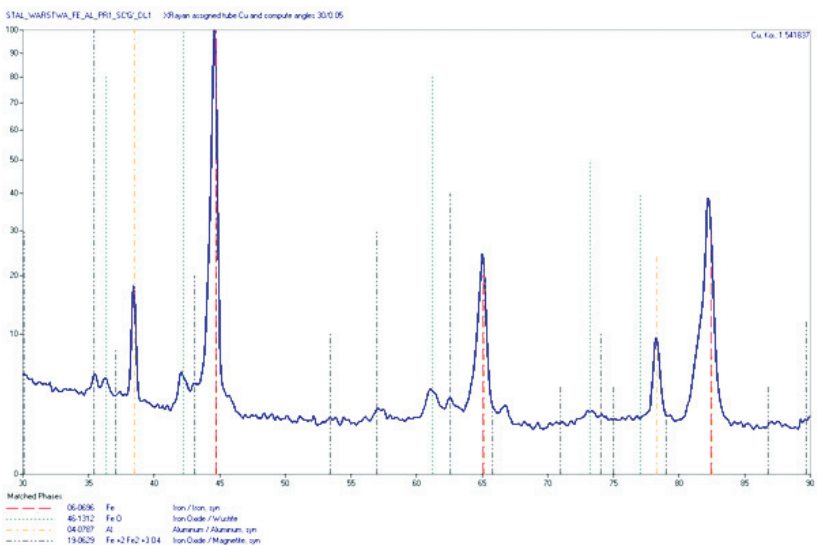

Rys. 5. Dyfraktogram XRD powłoki Fe-Al natryskiwanej łukowo Fig. 5. XRD diffractogram of the arc-sprayed Fe-Al coating

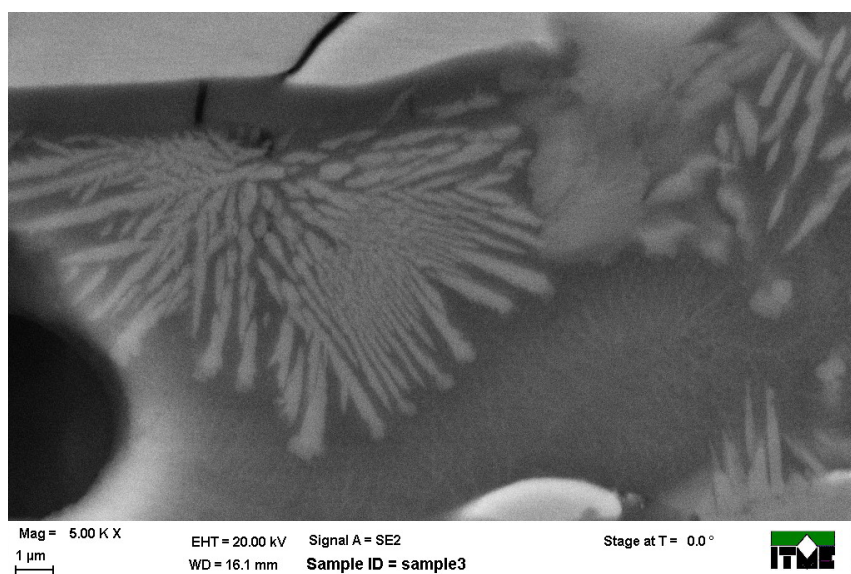

Rys. 6. Wydzielenia krystaliczne w granicy międzyfazowej krysztatów na osnowie Fe i Al

Fig. 6. Crystal secretions at the interface between crystals based on $\mathrm{Fe}$ and $\mathrm{Al}$

pierwiastków w obszarze przedmiotowych wydzieleń krystalizacyjnych. Otrzymane wyniki rozkładów liniowych (pokazane na rys. 7 i 8) na granicy faz wykazały obecność w strukturze zarówno faz tlenkowych, jak i faz międzymetalicznych z układu Fe-Al o różnym udziale atomowym żelaza i aluminium w tym ok. $50-50 \%$ oraz $80-20 \%$.

W kolejnym etapie analizy fazowej powłok wykonano badanie SEM powierzchni metodą spektroskopii efektu Mössbauera. Celem badania było zobrazowanie faz, które następnie będą analizowane z zastosowaniem tej techniki i porównanie składu chemicznego na powierzchni ze składem w przekroju próbek.
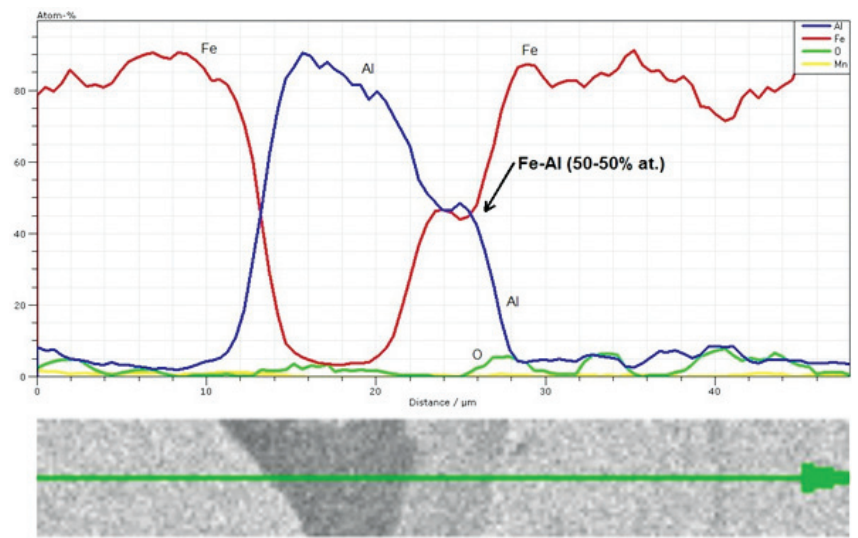

Rys. 7. Rozkład liniowy pierwiastków na granicy kryształów potwierdzający występowanie fazy Fe-Al o składzie ok. 50-50\% at

Fig. 7. Linear distribution of elements at the crystal border confirming the presence of the Fe-Al phase with the composition of approx. $50-50 \%$ at

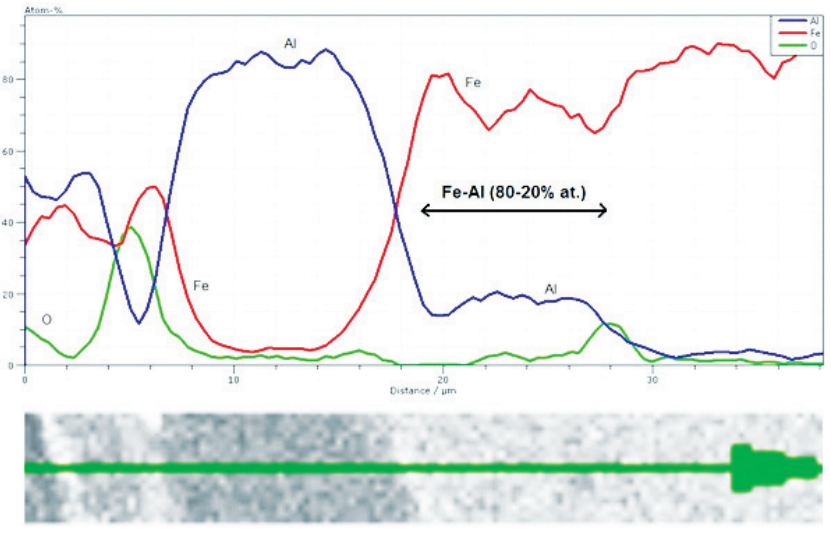

Rys. 8. Rozkład liniowy pierwiastków na granicy kryształów potwierdzający występowanie fazy Fe-Al o składzie ok. 80-20\% at

Fig. 8. Linear distribution of elements at the crystal border confirming the presence of the Fe-Al phase with the composition of approx. $80-20 \%$ at

Na rysunku 9 przedstawiono morfologię powierzchni, z której wynika znacznie mniejsza różnorodność faz niż w objętości powłoki, co potwierdza wpływ cyklu cieplnego powłoki po natryskiwaniu na jej strukturę fazową w kontekście układu nierównowagowego i cieplnej stymulacji syntezy faz międzymetalicznych. Na rysunku 10 przedstawiono mape rozkładu pierwiastków na powierzchni zewnętrznej natryskanej powłoki. Na rysunku kolorami zobrazowano rozkłady Fe i Al, pośredni kolor świadczy o występowaniu obu składników w objętości fazy. Miejsca takie zaznaczono strzałkami.

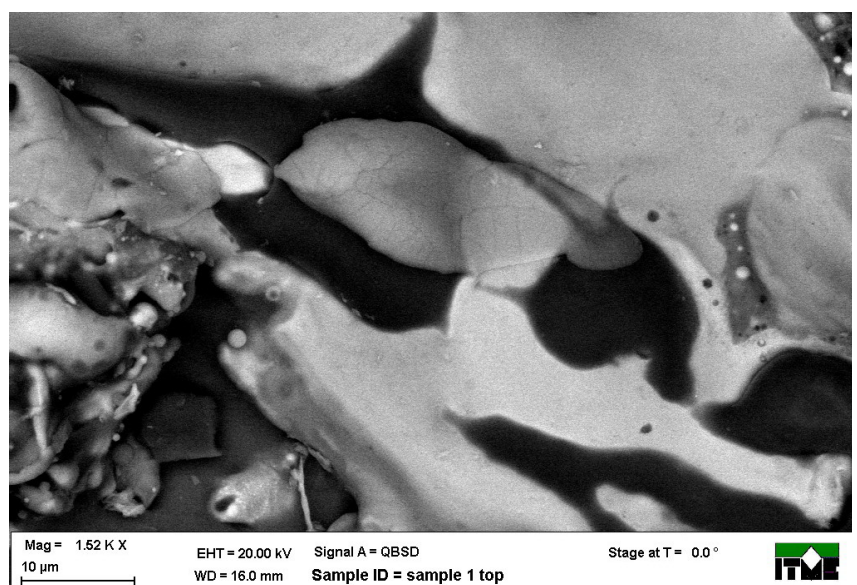

Rys. 9. Przykładowy obraz SEM powierzchni natryskanej powłoki Fig. 9. Sample SEM image of the surface of the sprayed coating

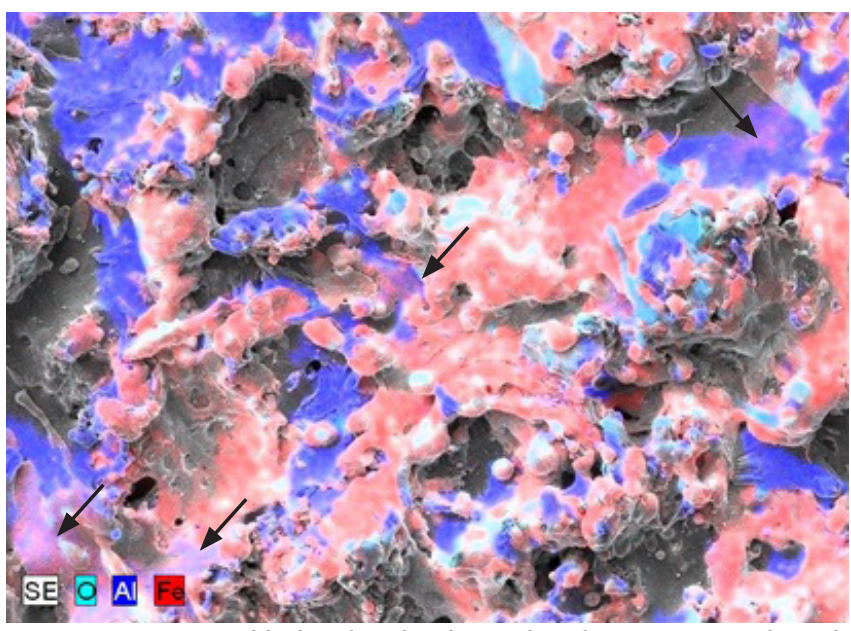

Rys. 10. Mapa rozkładu pierwiastków chemiczny występujących na powierzchni próbki powłoki

Fig. 10. Map of surface distribution of chemical elements occurring on the surface of the coating sample 


\section{Spektroskopia Mössbauerowska}

Dla dwóch losowo pobranych próbek powłok natryskiwanych wykonano pomiary metodą spektroskopii mössbauerowskiej elektronów konwersji CEMS (geometria rozproszeniowa), które dostarczyły informacji z warstwy powierzchniowej o grubości ok. 200 nm (pomiar uśredniony). Pomimo tego, iż widma CEMS cechuje wysokie tło, możliwe było wiarygodne dopasowanie składowych widm zarówno magnetycznych, jak i niemagnetycznych oraz jakościowe i ilościowe określenie rozkładu atomów Fe w różnych fazach.

Widma CEMS opracowano przy użyciu 4 składowych:

1) sekstet o polu nadsubtelnym $32,6 \mathrm{~T}$ (próbka 1) i 32,7 T (próbka 2) przypisany fazie bcc Fe, w której atomy $\mathrm{Al}$ nie występują w najbliższym sąsiedztwie atomów Fe, natomiast mogą być obecne $w$ dalszym sąsiedztwie;

2) sekstet o polu nadsubtelnym 29,3 T (próbka 1) i $29,8 \mathrm{~T}$ (próbka 2) przypisany bogatemu w Fe roztworowi stałemu bcc Fe(Al);

3) dublet kwadrupolowy przypisany paramagnetycznej fazie $\mathrm{Fe}(\mathrm{Al})$ bogatej w Al;

4) dublet kwadrupolowy przypisany fazie FeO.

W obu próbkach (rys. 11) w warstwach powierzchniowych zidentyfikowano jako główne fazy: (1) roztwór stały bcc Fe(Al) o zawartości Al w granicach $2 \div 20 \%$, (2) faza Fe(Al) bogata w Al, np. o składzie FeAl, ale nieuporządkowana (paramagnetyczna składowa 3 ). W próbce 1 zidentyfikowano niewielki udział tlenku żelaza FeO (składowa 4), ponadto nie można wykluczyć występowania śladowych ilości $\mathrm{Fe}_{3} \mathrm{O}_{4}$. Uśredniony pomiar warstwy powierzchniowej umożliwił ilościową analizę składu fazowego obu próbek: próbkę 2 cechuje mniejszy udział składowej pochodzącej od fazy bcc Fe z niewielką zawartością $\mathrm{Al}$, natomiast wyraźnie większy udział roztworu stałego bcc $\mathrm{Fe}(\mathrm{Al})$ o średniej zawartości Al ok. $15 \%$ (względny udział w widmie ok. $50 \%$ w porównaniu do ok. $30 \%$ dla próbki 1) i nieco mniejsza zawartość fazy Fe(Al) bogatej w Al (względny udział w widmie 7\% w porównaniu do $12 \%$ dla próbki 1). Stwierdzono, że w próbce 2 składniki Fe i Al przereagowały w większym stopniu niż w próbce 1.

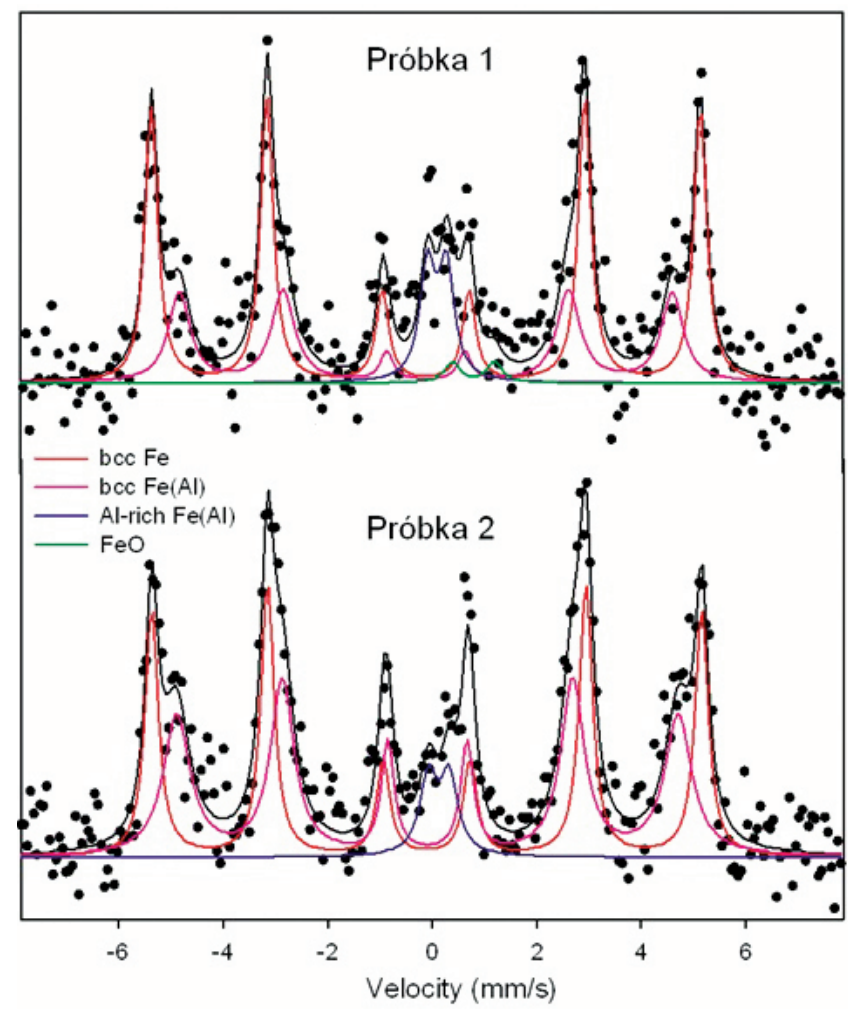

Rys. 11. Wyniki spektroskopii mössbauerowskiej

Fig. 11. The results of Mössbauer's spectroscopy

\section{Podsumowanie i wnioski}

Zrealizowano proces natryskiwania łukowego z jednoczesnym zastosowaniem dwóch różnych drutów elektrodowych Fe i Al. Po optymalizacji parametrów wytworzono w trakcie procesu powłoki kompozytowe Fe-Al, zawierającej w swej strukturze fazy międzymetaliczne $\mathrm{Fe}_{\mathrm{x}} \mathrm{Al}_{\mathrm{y}}$ o nieznacznym udziale objętościowym. Topiąc niezależnie dwa druty, jeden z żelaza drugi z aluminium wytworzono warunki termodynamiczne do powstania faz międzymetalicznych. Otrzymane powłoki posiadają strukturę wielofazową. W strukturze przeważają roztwory stałe na bazie żelaza oraz aluminium widoczne są również liczne tlenki żelaza i tlenki aluminium. Badania XRD nie wykazały występowania faz międzymetalicznych w minimalnej objętości identyfikowalnej tą metodą, aby badanie XRD wykazało istnienie danej fazy, jej udział objętościowy w badanej strukturze powinien być powyżej 5\%, co nie zostało osiągnięte podczas eksperymentu. Przeprowadzone szczegółowe badania EDS oraz pomiary metodą spektroskopii Mössbauerowskiej wykazały efekty syntezy między Fe i Al i istnienie fazy międzymetalicznej FeAl. Zastosowana przez autorów metoda wytwarzania powłok z układu Fe-Al stanowi alternatywę dla stosowanych w warunkach przemysłowych kosztownych rozwiązań bazujących na drogich proszkach metalicznych. Dalsze badania będą skierowane na optymalizację procesu natryskiwania, tak aby in-situ wytwarzać powłoki z większym udziałem objętościowym faz międzymetalicznych. W kolejnym etapie badań prowadzone będzie stymulowanie cieplne syntezy Fe i Al.

\section{Literatura}

[1] Chmielewski T., Golański D.: New method of in-situ fabrication of protective coatings based on Fe-Al intermetallic compounds, Proceedings of the Institution of Mechanical Engineers, Part B: Journal of Engineering Manufacture, vol. 225 (4), 2011, pp. 611-616.

[2] Shishkovsky I., Missemer F., Kakovkina N., Smurov I.: Intermetallics Synthesis in the Fe-Al System via Layer by Layer 3D Laser Cladding, Crystals vol. 3(4), 2013, pp. 517-529; doi:10.3390/cryst3040517.

[3] Dobrzański L.A., Dobrzańska-Danikiewicz A.D.: Kształtowanie struktury i własności powierzchni materiałów inżynierskich, Gliwice: Wydawnictwo Politechniki Śląskiej, 2013.
[4] Xu B., Zhu S., Ma S., Zhang W., Liu W.: Sliding wear behavior of Fe-Al. And Fe-Al/WC coatings prepared by high velocity arc spraying, Wear 257, 2004, pp.1089-1095.

[5] Senderowski C., Zasada D., Durejko T., Bojar Z.: Characterization of assynthesized and mechanical milled Fe-Al powders produced by the selfdisintegration method, Powder Technology 263, 2014, pp. 96-103.

[6] Sattari B., Shamanian M., Ashrafi A., Salehi M., Salimijazi F.: Effect of numer of passes on the corrosion behaviour of Fe/Al Surface composites produced by plasma spraying and friction stir processing, Journal of Materials Processing Tech. 250, 2017, pp. 35-44. 
[7] Wang H., Li C., Yang G., Li C.: Cold spraying of Fe/Al powder mixture: Coating characteristics and influence of heat treatment on the phase structure, Applied Surface Science 255, 2008, pp. 2538-2544.

[8] Amiriyan M., Alamdari H., Blais C., Savoie S., Schulz R.: Dry sliding wear behawior of $\mathrm{Fe} 3 \mathrm{Al}$ and $\mathrm{Fe} 3 \mathrm{Al} / \mathrm{TiC}$ coatings prepared by HVOF, Wear342343,2015 , pp. 154-162.

[9] http://quimica.udea.edu.co/ biomateriales/moodle/materiales/Intermetallics-\%20Applications.pdf

[10] Gontarz G., Chmielewski T, Golański D.: Modyfikacja natryskiwanych powłok aluminiowych na stali skoncentrowanym źródłem ciepła, Przegląd Spawalnictwa, vol. 83 (12), 2011, s. 52-55.
[11] Cebulski J., Bęczkowski R., Pasek D.: Wykonanie metodą napawania powłoki ze stopu międzymetalicznego FeAl na stali konstrukcyjnej, Przegląd spawalnictwa, vol. 89 (3), 2017, s. 36-39.

[12] Chmielewski T., Zhu S.: Natryskiwanie powłok na bazie wybranych faz międzymetalicznych metodą High Efficiency Hypersonic Plasma Spraying, Prace Naukowe Politechniki Warszawskiej. Mechanika, 2006, s. 49-58

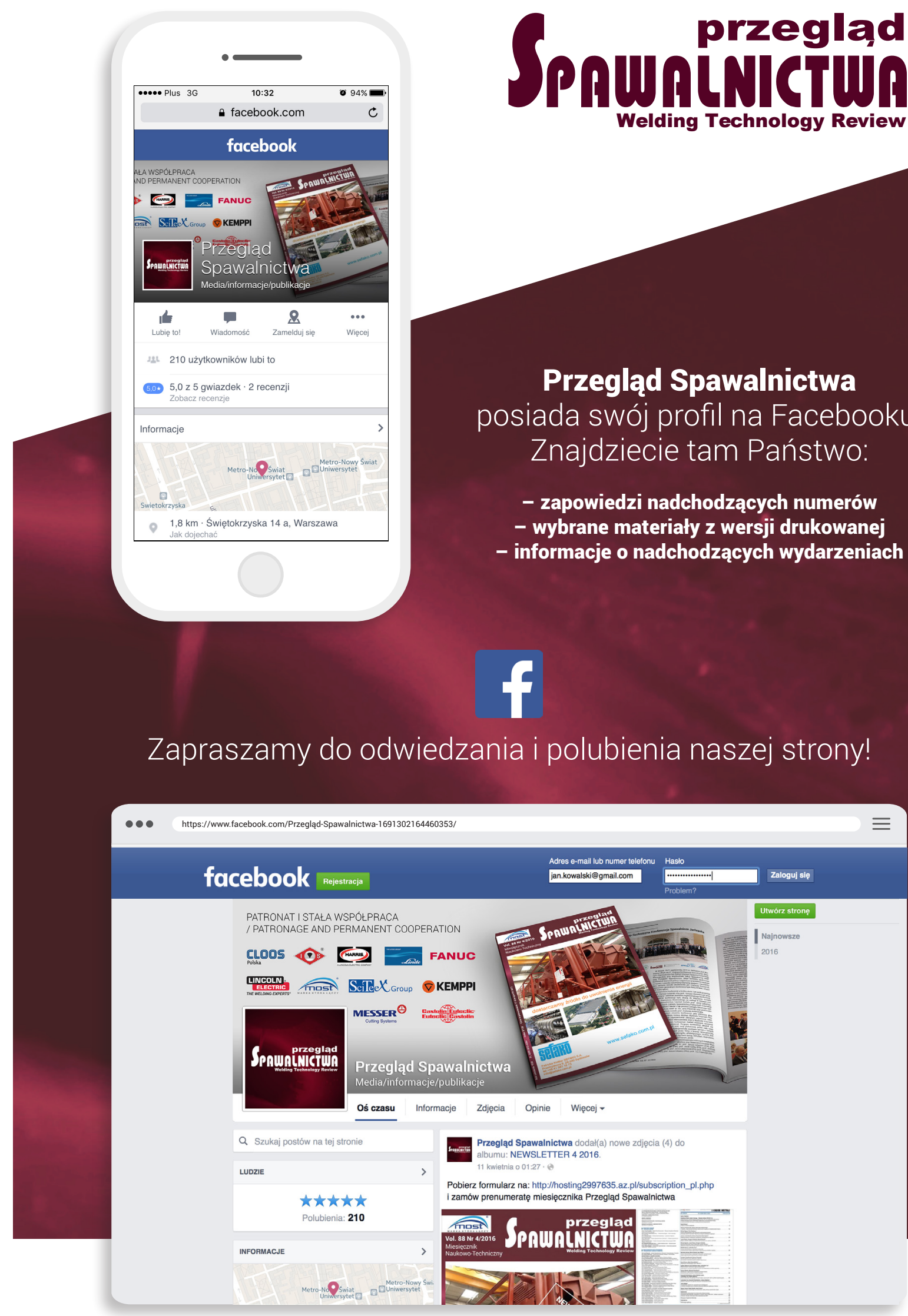

$\equiv$ 